\title{
on_education
}

Journal for Research and Debate

\section{the more, the better: academics between organizational demands for internationalization and standards of the scientific community}

\author{
Roland Bloch and Manfred Stock
}

\begin{abstract}
According to the Times Higher Education World University Ranking, the 'most international' universities of the world are the Universities of Luxembourg and Qatar. They display the highest shares of international students, staff, and collaborations - indicators taken for assessing an internationality that positions the university in a global competition. Their scores are communicated as benchmarks of internationality, as a sign of a university's competitiveness. Consequently, universities around the world as well as whole national higher education systems seek to become 'more international'.
\end{abstract}

According to the Times Higher Education World University Ranking, the 'most international' universities of the world are the Universities of Luxembourg and Qatar. 1 They display the highest shares of international students, staff, and collaborations - indicators taken for assessing an internationality that positions the university in a global competition. Their scores are communicated as benchmarks of internationality, as a sign of a university's competitiveness. Consequently, universities around the world as well as whole national higher education systems seek to become 'more international'. German universities are audited for their internationalization strategy (Bloch et al., 2018). French grandes écoles are forced to admit international students and to offer courses in English (Schippling, 2018). Irish universities struggle to attract international students for whom they are only second choice after UK universities (Courtois, 2018). Internationality demands escalation: the more international, the better. One university has 10 international partners, the other 100; the logic of escalation implies that the latter is superior to the former. All in all, internationality has become a means for the vertical positioning of universities, both nationally and globally. As organizational members, academics are expected to enhance their university's internationality, and experience considerable pressure to 'internationalize' in research and teaching.

In the following, we take a closer look on this link between internationality and vertical positioning. Conspicuously, current discourses and practices of internationalization presume attributions to the nation-state, either implicitly or explicitly. Thus, (1) we analyse the relation between universities and the nation-state. We ask which structural elements and activities of universities are rather embedded in the nation-state, and which of those transcend the national frame. Subsequently (2), the findings are confronted with those attributes that universities' current internationalization efforts relate to. This allows us to describe in what sense these attributes are suited for vertical distinctions, as well as to account for the effects of taking internationality as a marker of superiority.

1. Universities between the nation-state and global standards of scientific universalism 
In their history and their structure, universities are related to the nation-state but also reach beyond it. Already the medieval European universities were universal in character because their curriculum was based on universal religious terms. Unlike today, these early universities often had no permanent facilities; they were not tied to a certain place or territory. Students as well as professors could easily move from one location to another. Universities were founded in cities, maybe transferred to another place, or closed. Although it would be wrong to call them supra-national since this would presuppose nation-states which did not exist at that time - they were nevertheless characterized by a specific, religiously founded universalism.

With the gradual transition to the modern research university during the 18th and 19th centuries, starting in Germany, the content of this universalism changed. Now it became a specific scientific universalism, and the university was based on the freedom of research and teaching. The objects of scientific research and teaching were to be selected according to science's own criteria, as well as the evaluation of scientific work. Researchers were expected to publish their results, which led to the establishment of specialist journals. More and more academic disciplines were founded. At first these disciplines developed their communicative context within national scientific communities. But the growth of ever more specialized disciplines soon transcended national borders. It became unlikely that collegial relations were confined to the national context (Stichweh, 2000). A worldwide scientific community emerged. Its disciplinary structure still determines the basic characteristics of university curricula.

As organizations, however, universities were still subjected to political powers, which since the eighteenth and nineteenth centuries had taken on the character of rivalling nation-states. In Germany, as well as in other continental European higher education systems, universities educated primarily civil servants, and state exams were introduced as a means of state control. Universities were central to nation-building (Riddle, 1996). Nevertheless, state control and financing could only relate to the university as an organization. The core activities of the university, research and teaching, may take place locally but have to prove their value globally. The "communal character" (Merton, 1959, p. 557) of science is per se cosmopolitan and universally inclusive. Scientific universalism (cf. Scott, 1998) demands that you cannot teach a theory in a German seminar which has already been refuted in an American research institute. Thus, although the formal structures of universities in varying degrees continue to be controlled by the state, the core activities of research and teaching follow universal standards. These standards are beyond the organization's influence; they cross national borders and are reproduced by global scientific communities. Accordingly, scientific knowledge claims to be universally valid, is universally accessible, allows for universal learning, and can be criticized universally.

With regard to research, this means that cooperation in the network of scientific communities cuts across the university as an organization. Though universities provide the infrastructure and resources for cooperation, they cannot prompt or control it. Rather, cooperation - and also that which brings together researchers of different nationalities - arises primarily from factual interests of researchers, and is therefore withdrawn from being instrumentally appropriated by the organization. If research results are claimed to be valid, they need to be published. Increasing crossborder research cooperation is mirrored by an increasing number of co-authorships (Baker et al., 2015, p. 20ff). Evaluation procedures (peer review) are equally based on universal standards, and thus defy control through the organization, too. The same holds true for the dissemination and accumulation of reputation. The significance of universities is reduced to the provision of addresses (cf. Stichweh, 2009) in order to render nodal points in the net of cooperative relations attributable. 
In this sense, universities are used by scientific communities for their purposes. However, universities can increase the attractiveness of their addresses by providing extra resources for research, thereby improving the prospects of the involved researchers for the accumulation of reputation, which in turn can be allotted to the organization.

With regard to teaching, the universal character is manifest in tertiary education's inherent inclusiveness. Notwithstanding prevailing practices of discrimination, scientific universalism regards all persons as potential students, irrespective of age, gender, nationality, or ethnicity. During the twentieth century, higher education transitioned from elite to mass higher education, and more recently to universal access (Trow, 2006). The number of students is increasing worldwide (Schofer \& Meyer, 2005), as well as the shares of previously excluded groups - for example, women (Bradley \& Ramirez, 1996). In general, ascriptive criteria are becoming less important.

\section{Internationality as a resource for vertical positioning}

Current discourses and practices are characterized by a strategic view of internationalization. Universities' efforts are directed at becoming more international. Both in self-accounts of universities and in political guidelines, internationality is communicated as a valuable end in itself. No factual references are made to the core activities of research and teaching. For instance, one aims to increase the share of foreign researchers and students, but does not specify how this may eventually support research and teaching.

The valuation of internationality as a goal of universities appears to be unquestionable, because it seems to correspond to the universal and border-transcending character of research and teaching. If this holds true then the goal of internationality is redundant. The programmatic focus on internationality serves no factual function; it is not tied to the material characteristics of research cooperation or teaching. Rather, the function of internationality is social in the sense that it allows for positioning the university in the field of higher education. To this end, internationalization transforms elements of scientific universalism into indicators which produce ranking effects. The elements themselves elude a logic of escalation, for example, the opportunity for (e.g., Chinese) researchers to criticize other (e.g., German) researchers' results based on commonly accepted grounds in collaborations, publications, or at conferences. In contrast, the share of Chinese students or professors from a US-background, the number of accreditations by international agencies or partnerships with foreign universities, amongst other indicators, all lend themselves to a ranking logic, and can therefore be used as indicators to position an organization strategically in the field.

While the development of international cooperation based on common factual research interests cannot be controlled by the organization, the aforementioned indicators of internationality and guidelines for internationalization, are easy to measure and report in their implementation. They enable comparisons between organizations that can be communicated and used for claiming superiority and staging positioning gains. Such stagings follow a logic that has been described very accurately by Bettina Heintz: "The 'better' part distinguishes itself from the others and represents at the same time the overall order of which it is a part. Through this, the special is declared to be the general and derives from this its legitimacy“ (transl. Heintz, 2010, p. 165).

That internationality is used as a resource for generating rank differences between higher education organizations corresponds to this overall order. From the organizational point of view, the factual collaboration of a researcher with a foreign researcher, which originates in common research topics 
and a common desire to advance them, is not of interest. Rather, the focus is on their contact as an abstract value. Not the material interest in cooperation based on a common case counts, but the sheer contact as a parameter in a balance sheet of contacts, which is taken for telling something about a university's level of internationality. With the ranking of universities, a resource logic based on abstractions of reality permeates the organizational level.

Thus, we are dealing with a situation which Georg Krücken and Frank Meier have described as the "transformation of universities into organizational actors, which are able to act strategically and position themselves with regard to their competitors“ (2006, p. 242). The institutionalization of attributes of strategic actorhood is paralleled by the institutionalization of a resource logic based on abstractions of reality. Thus, activities in research and teaching assume an ambivalent character. Next to factual content-related considerations in research and teaching, more and more aspects that follow a resource logic gain in prominence. Both sides conflict with each other, and these conflicts penetrate the academic role.

For this role, two aspects are constitutive: on the one hand, academics are members of the scientific community, on the other hand, they have to conform to formal expectations tied to their role as members of the organization 'university'. Their role as a member of the scientific community is matched by the factual interest in cooperation with researchers, regardless whether their address is that of a neighbouring domestic university or an Ivy League university overseas. Cooperation happens on the basis of criteria that are inherent to scientific universalism, and that presuppose different addresses to be of equal value. This is the common ground on which content-related points of contact are sought. Under the auspices of organizational programs to advance internationalization, these aspects become secondary. They are substituted by abstractions that disregard the substantiality of the cooperative content and reduce it to an empty value, a mere unit of connecting addresses that is integrated into a quantitative value of describing internationality. This value is determined precisely by its indifference vis-à-vis material and content-related aspects.

As organizational members, academics are forced to cope with this resource logic that is external to their factual interests. It is imposed on them by formal rules that are difficult to elude as an organizational member. Academics' alternatives for action can be accounted for with Merton's anomy theory as apathy (indifference), ritualism, conformity, innovation, and rebellion. It is, then, an empirical question which course of action is taken. Each alternative causes specific costs that may also differ between research and teaching. However, it may be helpful to remember Nils Brunsson's $(1982,1993)$ instructive distinction between 'talk', 'decision-making' and 'action' in organizations: organizational members' actions (in universities: research and teaching) may deviate from self-accounts represented to the outside, as well as from organizational programs (in this case: to enhance internationality). The loose couplings between different organizational levels may even be functional for the organization. However, the members still have to act on demands put forth by formal structures. It is precisely this imperative that causes problems. In a ranking-driven environment, universities have to act strategically, and internationalization is one example how they do so. To enhance internationality, they substitute content-related motives for practices of accounting. Though internationality per se corresponds with scientific universalism, this does not create a win-win-situation between the university and its members as long as accounting for internationality, devoid of any content, is the dominant motive.

References 
Baker, D., Crist, J. T., Zhang, L., Powell, J. W., Shima, K., \& Stock, M. (2015). Science Productivity, Higher Education Development and the Knowledge Society (SPHERE Project). Final Report. Open Repository and Bibliography

http://orbilu.uni.lu/bitstream/10993/22339/1/SPHERE_QNRF\%20Final\%20Report\%20NPRP\%20 5-1021-5-159.pdf

Bloch, R., Kreckel, R., Mitterle, A., \& Stock, M. (2018). Stratification Through Internationality in German Higher Education. In Maxwell, C., Deppe, U., Krüger, H., \& Helsper, W. (Eds.), Elite Education and Internationalisation. From the Early Years to Higher Education (pp. 257-278). Cham: Palgrave Macmillan.

Bradley, K., \& Ramirez, F. O. (1996). World polity and gender parity: women's share of higher education, 1965-1985. Research in Sociology of Education and Socialization, 11, 63-91.

Brunsson, N. (1982). The Irrationality of Action and Action Rationality: Decisions, Ideologies and Organizational Actions. Journal of Management Studies, 19(1), 29-44.

Brunsson, N. (1993). Ideas and actions. Justification and hypocrisy as alternatives to control. Accounting, Organizations and Society, 18(6), 489-506.

Courtois, A. (2018). The Global Ambitions of Irish Universities: Internationalizing Practices and Emerging Stratification in the Irish Higher Education Sector. In Bloch, R., Mitterle, A., Paradeise, C., \& Peter, T. (Eds.), Universities and the production of elites. Discourses, policies, and strategies of excellence and stratification in higher education (pp. 127-148). Cham: Palgrave Macmillan (Palgrave studies in global higher education).

Heintz, B. (2010). Numerische Differenz. Überlegungen zu einer Soziologie des (quantitativen) Vergleichs. Zeitschrift für Soziologie, 39(3), 162-181.

Krücken, G., \& Meier, F. (2006). Turning the University into an Organizational Actor. In Drori, G. S., Meyer, J. W., \& Hwang, H. (Ed.), Globalization and organization. World society and organizational change (pp. 241-257). Oxford, New York: Oxford University Press.

Merton, R. K. (1959). Social theory and social structure. Glencoe: The Free Press.

Riddle, P. (1996). The university and political authority: Historical trends and contemporary possibilities. Research in Sociology of Education and Socialization, 11, 43-62.

Schippling, A., Zimmermann, J., \& Schmidt, M. (2018). Academic Identity Constructions of the Écoles Normales Supérieures and the Challenges of Internationalization. In Bloch, R., Mitterle, A., Paradeise, C., \& Peter, T. (Eds.), Universities and the production of elites. Discourses, policies, and strategies of excellence and stratification in higher education (pp. 349-371). Cham: Palgrave Macmillan (Palgrave studies in global higher education).

Schofer, E., \& Meyer, J. W. (2005). The Worldwide Expansion of Higher Education in the Twentieth Century. American Sociological Review, 70(6), 898-920.

Scott, P. (1998). Massification, internationalization and globalization. In Scott, P. (Ed.), The globalization of higher education (pp. 108-129). Buckingham, England and Philadelphia, PA: Society for Research into Higher Education and Open University Press.

Stichweh, R. (2000). Die Weltgesellschaft. Frankfurt a.M.: Suhrkamp

Stichweh, R. (2009). Die Universität in der Weltgesellschaft. Akademische Rede am Dies Academicus der Universität Luzern am 1. Oktober 2009. Retrieved September 10, 2018, from

https://www.fiw.uni-bonn.de/demokratieforschung/personen/stichweh/pdfs/74_universitaet-in-derweltgesellschaft.pdf

Trow, M. (2006). Reflections on the Transition from Elite to Mass to Universal Access: Forms and Phases of Higher Education in Modern Societies since WWII. In Forest, J. J. F., \& Altbach, P. G. (Eds.), International Handbook of Higher Education. Regions and countries (pp. 243-280). New York: Springer. 


\section{Recommended Citation}

Bloch, R. \& Stock, M. (2018). The More, the Better: Academics Between Organizational Demands for Internationalization and Standards of the Scientific Community. On Education. Journal for Research and Debate, 1(3). https://doi.org/10.17899/on_ed.2018.3.1

\section{Download PDF version}

Do you want to comment on this article? Please send your reply to editors@oneducation.net. Replies will be processed like invited contributions. This means they will be assessed according to standard criteria of quality, relevance, and civility. Please make sure to follow editorial policies and formatting guidelines.

\section{roland bloch \& manfred stock}

Roland Bloch is research associate at the Center for School and Educational Research at Martin-Luther-University Halle-Wittenberg. His main research interests are the structure and organization of academic work, stratification in higher education, and the genesis as well as implementation of higher education reforms. His latest publication is the edited volume "Universities and the Production of Elites. Discourses, Policies, and Strategies of Excellence and Stratification in Higher Education" (Palgrave Studies in Global Higher Education, together with A. Mitterle, C. Paradeise, and T. Peter). Manfred Stock is Professor of Sociology of Education at the Martin-Luther-Universität Halle-Wittenberg in Germany. Since 2002, he has been a senior scientist at Wittenberg Institute for Research on Higher Education.

1. This article is based on research undertaken within the DFG research unit "Mechanisms of Elite Formation in the German Educational System" (FOR 1612), sub-project "Elite Formation and Universities". 